\title{
Customer Retention and Related Factors Analysis in Financial Services Company
}

\author{
Heru Santosa Hadiyanto* \\ Management Department, BINUS Business School Undergraduate Program, \\ Bina Nusantara University \\ Jln. K. H. Syahdan No. 9, Jakarta Barat 11480, Indonesia \\ heru.hadiyanto@binus.ac.id
}

Received: $1^{\text {st }}$ July $2020 /$ Revised: $14^{\text {th }}$ September 2020/ Accepted: $20^{\text {th }}$ October 2020

How to Cite: Hadiyanto, H. S. (2021). Customer Retention and Related Factors Analysis in Financial Services Company. Binus Business Review, 12(2), 93-101. https://doi.org/10.21512/bbr.v12i2.6546

\begin{abstract}
High competition requires companies to maintain their consumers, so they do not turn to competitors. Besides that, the high acquisition cost to get new customer makes many companies shift their focus to customer retention. It also happens in the financial services industry in Indonesia. Their product is relatively homogeneous with tight regulations, price war from competitors, and the high credit risk to acquire new customers. It makes finance companies concentrate on consumer retention. The research aimed to identify the factors that most influence consumer retention in the financial services company. Cluster random sampling technique was applied to get the sample of the population. Secondary data from one branch of a finance company in a particular geographical cluster (2.858 customers) were used. The selection of branches or geographical clusters was selected randomly. Data analysis was conducted based on several determinant factors that affected consumer retention, such as the amount of loan to value, days past due that consumers had, monthly income, and the mileage from the customer domicile to the company offices. Pearson correlation analysis was used to analyze these determinant factors. Based on several factors, mileage and loan to value have a highly significant relationship with customer retention. Meanwhile, the other variables do not have a significant effect on customer retention.
\end{abstract}

Keywords: customer retention, loan to value, days past due, monthly income, customer mileage, financial services company

\section{INTRODUCTION}

High competition requires companies to continue to maintain and increase customer loyalty. Along with increasing customer loyalty, it is expected to create repeat orders from these consumers (Kangu, Wanjau, Kosimbei, \& Arasa, 2017). Loyal customers will buy more, and they can also act as promoters to create other prospects (Hague \& Hague, 2016). Therefore, customer service is a positive thing to increase company revenue (Karya, Suhartono, Candra, 2017). So, it is essential for a company to pay special attention to customer satisfaction because it will generate a stable income for the company (Idrees \& Xinping, 2017; Almohaimmeed, 2019).

Similar conditions occur in companies in financial services, such as multi-finance companies.
As a company in the service, consumer loyalty is very important to build long-term relationships. Building long-term relationships begin with fostering positive relationships with customers to keep their loyalty and satisfaction (Alfansi, 2016; Pansari \& Kumar, 2017). In the end, customer satisfaction will influence consumer retention (Mahapatra \& Kumar, 2017; Haripersad \& Sookdeo, 2018). One of the previous research about financial industries reveals the need for "proactive retention", namely taking precautions to secure customer loyalty (Larsson \& Broström, 2019).

However, another research shows that customer satisfaction is not enough to keep customer loyalty to the company (Monferrer, Moliner, Estrada, 2019). Customer loyalty can be reflected in customer retention in making a repeat purchase (Scarff, 2017; Daneshfar, Roshani, \& Sabzali, 2016; Nguyen, Nguyen, Nguyen, 
\& Phan, 2018). Higher retention will impact higher market share, which in turn results in higher income (Kyei \& Bayoh, 2017). In other words, consumer retention is the key to healthy business growth (Magatef \& Tomalieh, 2015). The existing customers can be effectively maintained if they have the potential to generate better income than new customers (Kuria \& Muturi, 2018).

Some previous studies discuss consumer retention, but there are still contradictions between one study and other studies. For example, previous research analyzes the effect of a consumer loyalty program in increasing consumer retention in Jordan. The results reveal that the influence mainly came from the tiered reward system and charge fee for VIP benefits (pricing reward). This consumer loyalty program is a form of customer relationship management (Magatef \& Tomalieh, 2015). On the contrary, another research highlights the role of customer relationship management on the level of consumer retention and profitability in the pharmaceutical industry in Tunisia. From this research, it is known that there is no significant relationship between the application of customer relationship management to consumer retention. In addition, the results suggest that there is no significant relationship between customer relationship management and profitability (Bahri-Ammari \& Soliman, 2016). It is certainly different from other studies which suggest a significant influence between customer retention and income (Kuria \& Muturi, 2018). Another example states that sales promotion significantly increases customer retention (Chen \& Green, 2011; Mendez, Bendixen, Abratt, Yurova, \& O'Leary, 2015). However, other studies reveal that sales promotion does not significantly influence consumer retention (Hanaysha, 2018).

Several researchers define customer retention. It is described as many customers who stay with service providers for a specified period, like in one year (Idrees \& Xinping, 2017). It is also a form of customer behavior that companies want to manage so that the customers can be in continuous contact (Ascarza et al., 2018). Meanwhile, another research mentions that customer retention is about overall initiatives to reduce customer turnover (Ling, 2017). In the research, consumer retention illustrates how often consumers often make repeat purchases in a certain period through marketing strategies by the company.

Based on some of the explanations, it can be concluded that customer retention plays a crucial role for the company to maintain its existence in high business competition. According to Haripersad and Sookdeo (2018), the main challenges in the financial industry are cost control and customer retention. Ironically, this contradictory condition is currently experienced by a finance company. Within 18 months, the sales composition of its existing customers continues to experience a downward trend from $42 \%$ to $29 \%$, in line with the continued increase in their customer base (see Table 1). It reflects a problem in retaining consumers.
Table 1 Sales Composition

of Customer Retention vs. New Acquisition

\begin{tabular}{ccc}
\hline \multicolumn{3}{c}{ Sales by Customers } \\
\hline Month (N) & Repeat Order & New \\
\hline N-15 & $42 \%$ & $58 \%$ \\
N-14 & $35 \%$ & $65 \%$ \\
N-13 & $50 \%$ & $50 \%$ \\
N-12 & $40 \%$ & $60 \%$ \\
N-11 & $40 \%$ & $60 \%$ \\
N-10 & $33 \%$ & $67 \%$ \\
N-9 & $42 \%$ & $58 \%$ \\
N-8 & $40 \%$ & $60 \%$ \\
N-7 & $35 \%$ & $65 \%$ \\
N-6 & $37 \%$ & $63 \%$ \\
N-5 & $49 \%$ & $51 \%$ \\
N-4 & $38 \%$ & $63 \%$ \\
N-3 & $35 \%$ & $66 \%$ \\
N-2 & $40 \%$ & $60 \%$ \\
N-1 & $29 \%$ & $71 \%$ \\
\hline
\end{tabular}

As a financial services provider that is undermonitoring by government regulation and has homogeneous product characteristics, the priority to retain consumers is very important for the business sustainability. The main challenges in the financial industry today are cost control and customer retention (Haripersad \& Sookdeo, 2018). In general, finance companies make profits through two main activities: customer acquisition and customer maintenance. Customer acquisition relates to how financial service providers offer financial service products and select consumers who meet the eligibility standards for credit facilities. Meanwhile, customer maintenance refers to billing activities to maintain payment collectability and ensure the implementation of customer service standards so that consumers want to make a repeat purchase in the company (customer retention).

Based on the results of other secondary data analysis, it is known that there are four reasons for customers to cancel the refinancing process. First, they have not required a credit loan yet $(21 \%)$. Second, it has a small loan of value (19\%). Third, they are not willing to come to the branch office $(16 \%)$. Last, it has a complex credit process $(15 \%)$. Customers do not require credit loans, which are thought to occur because of the monthly income.

Meanwhile, they are not willing to come to the office because of the distance factor. These four factors are also revealed by Kyei and Bayoh (2017). There is a relationship between product, process, marketing, and service variables to customer retention. Product and marketing are quite identical with the aspects of loan to value and customer income because, in the context of granting credit, these two aspects must be seen together. The process variable is identical to mileage 
because mileage makes it easier for customers to come to the office. Then, service is related to a complex credit process. It is reflected in the historical days past due as main consideration factors to create a simple credit process.

From other secondary data and previous research, several research questions regarding several factors influence the level of consumer retention. These questions will be the basis for developing further research hypotheses. (1) Is the retention of these consumers affected by how much the disbursement is related to the given guarantee to them (loan to value)? (2) Does the mileage from the domicile of consumers to the company's office affect the level of customer retention? (3) Does the customer's monthly income affect the level of consumer retention? (4) What are the credit quality factors (days past due) that influence the level of customer retention?

Customer retention is determined by pricing factors, such as interest rates, the value of the obtained collateral, and the costs imposed on these consumers. The higher or more expensive the interest rates are imposed, the consumers do not tend to take credit again in the company. Besides that, they prefer to look for other loan options in competitors with lower pricing levels. Likewise, the amount of credit disbursement that can be given is identical to the level of consumer retention. Based on this premise, the first hypothesis can be drawn as follows:

H1: The previous loan to value is positively and significantly correlated with customer retention.

Another factor related to consumer retention is credit quality or the quality of payments from these consumers before. Credit quality can be reflected in the number of arrears days experienced by these consumers. The higher day of delay that consumers have experienced reflects the quality of credit that is increasingly risky. With an increasingly high level of risk, the possibility of consumers switching to competitors is also smaller because competitors will also be more stringent in providing credit facilities. Based on this premise, the second hypothesis is as follows:

$\mathrm{H} 2$ : Historical days past due from previous payment is negatively correlated and significantly with customer retention.

Another determinant factor that is thought to influence consumer retention is customer income. This factor is expected to be sufficient to influence consumer retention because the segmentation of finance companies is more likely to lead in the lower middle segment. The higher the monthly income of the consumers is, the higher the economic level will be. If consumers' income is relatively low, they tend to need credit. Thus, the lower level of consumers' income is identical to a high level of consumer retention. Based on this thinking, the third hypothesis is as follows:
H3: Customers' monthly income is negatively and significantly correlated with consumer retention.

According to the business process in a finance company, there is a consumer obligation to come to the office regularly for each sale transaction. It starts from the customer acquisition stage that the consumers are asked to come to the office for interviews about the feasibility of granting credit facilities. Sometimes, consumers must return to the branch office to make monthly payments and take collateral when the credit obligations have ended. With these activities, it is suspected that there is an influence between distance or travel time (accessibility) that must be done by these consumers with the level of customer retention. The closer distance to the office location is identical with a higher retention rate. The fourth hypothesis can be drawn as follows:

H4: The mileage from the consumers' domicile to the company's office is negatively and significantly with consumer retention.

Based on the framework, the descriptive research is conducted by analyzing consumers' data to determine how the behavior and characteristics are and linking it with the mileage factor. The analysis results will be used to provide recommendations regarding what the financing service provider must do to resolve customer retention issues.

\section{METHODS}

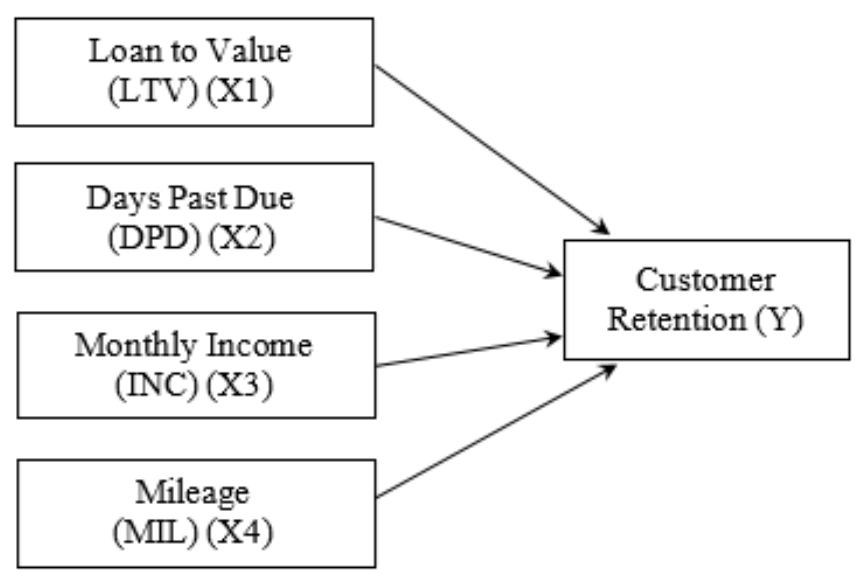

Figure 1 Research Model

Based on the several hypotheses, a research model can be seen in Figure 1. The research is carried out by using a two-step approach. The research uses a statistical tool, Statistical Package for Social Science (SPSS), in the first stage. Because the used data are interval data, bivariate correlation analysis techniques are applied to test the hypotheses that have been mentioned and to find out which variables that most significantly affect consumer retention. 
In the second stage, the research is conducted by using the descriptive method. The research collects actual data and compiles, processes, and analyzes it to describe the existing problems. This method is used to obtain a picture of the facts, properties, and relationships of the state of the object to be examined. With a descriptive analysis, it is expected to provide an overview of the characteristics of consumers based on the variables that have the most significant influence, along with what the company must do.

Then, the cluster random sampling technique is used to get the sample of the population. Secondary data from one branch of a finance company in a particular geographical cluster (2.858 customers) are used. Then, the period of the conducted analysis is in the latest four years. The selection of branches or geographical clusters is selected randomly. The used data are the first sales order from each consumer. It is linked to subsequent sales to see which consumers cannot be retained and consumers who are retained once, twice, and so on. Thus, it will be known why these consumers can withdraw and take financing later from their first contract.

Table 2 The Research Variable

\begin{tabular}{lll}
\hline Variable & Code & Detailed \\
\hline $\begin{array}{l}\text { Customer } \\
\text { Retention }\end{array}$ & RET & $\begin{array}{l}\text { Frequently sales at last } \\
\text { five years (times) } \\
\text { Loan to Value }\end{array}$ \\
$\begin{array}{lll}\text { Mayimum disbursement } \\
\text { from collateral value (\%) }\end{array}$ \\
$\begin{array}{l}\text { Monthly } \\
\text { Income }\end{array}$ & INC & $\begin{array}{l}\text { The maximum period of } \\
\text { default payment (days) } \\
\text { reflects economic class } \\
\text { (Rp) }\end{array}$ \\
Mileage & MIL & $\begin{array}{l}\text { Mileage from customer's } \\
\text { residence to a branch } \\
\text { office (km) }\end{array}$ \\
\hline
\end{tabular}

Table 2 shows the research variables. The loan to value is measured by the ratio between the credit disbursement to the collateral value that is used as a guarantee by the consumers. The used data are interval scale data. The data will be grouped into five interval scales in statistical tests, from the largest (5) to the smallest (1). The second variable is days past due. The credit quality or payment quality from these consumers reflects the level of risk for these consumers. Measurement of this variable refers to historical data of consumers' payments, namely how long installment past due days or late of payment in credit obligations. These data will be grouped into five scales: the least number of days in arrears (5) to the highest number of days in arrears (1).

The third variable, economic class, is measured based on the level of the monthly income of each consumer. Revenue data are the secondary data obtained from the company. These data will be grouped into five scales from the highest income (5) to the lowest income (1). Then, the fourth variable, mileage, represents the distance of the consumers' domicile from the company's office location. The research uses Geography Information System tools to identify. Using this system, the distance refers to the distance on the map, not the distance, which in practice is clearly full of uncertainty, such as traffic jams that may be experienced at certain hours. The obtained consumers' domicile data will be grouped into five scales, from the closest radius (5) to the farthest radius (1) from the branch office location.

\section{RESULTS AND DISCUSSIONS}

The description of the interval scale data for each variable in research is summarized in Table 3. Five interval scales group each variable. Customer retention (Y) represents the sales frequency by customer. An interval scale of 1 shows one sales frequency or zero retention by customer. Meanwhile, the interval scale of 2 is two sales frequencies or one-time retention, and so on. Then, loan to value (X1) represents how big the loan given to the consumer is. It is related to the collateral. An interval scale of 1 shows the previous loan given to customers in the range of $55-60 \%$ from collateral value. Then, an interval scale of 2 means the previous loan given to customers in the range $60-65 \%$ from collateral value, and so on.

Next, days past due (X2) shows the maximum customers' past due to pay the credit installment. Meanwhile, monthly income (X3) refers to the customers' economic class and capacity. Then, mileage (X4) represents how far customers' domicile from the company office location. An interval scale of 1 means the customers stay in a radius of $0-2 \mathrm{~km}$ from the company office location. Meanwhile, an interval scale of 2 shows that the customers stay in a radius of 2-4 km from the company office location, and so on.

The data in the analysis are 2.858 consumers. In general, the characteristics of consumers are illustrated in Table 4. According to the customer retention column, eight times are the highest frequency of sales by customers. On average, sales frequency per customer is 1,5 times. It means that customers only book 1-2 times of sales frequency averagely. Then, the loan to value reflects the average of the loan given to the customers. The average loan to value is $67,08 \%$, and the range of customers is from $50 \%$ to $84 \%$. Next, days past due shows that the range of past due by customer is 0 day (excellent payment history) until 116 days (bad payment history), with average days past due of 39,98 days per customer. Meanwhile, monthly income spreads from the range of $\mathrm{Rp} 2.100 .000$ to $\mathrm{Rp} 4.030 .000$, with an average point of $\mathrm{Rp}$ 2.949.458. Last, mileage represents the distance from the company office to customers' residents from $2-24 \mathrm{~km}$, with an average of $5,8 \mathrm{~km}$. 
Table 3 Research Variable and Measurement

\begin{tabular}{cccccc}
\hline $\begin{array}{c}\text { Interval } \\
\text { Scale }\end{array}$ & $\begin{array}{c}\text { RET } \\
(\mathbf{Y})\end{array}$ & $\begin{array}{c}\text { LTV } \\
(\mathbf{X} 1)\end{array}$ & $\begin{array}{c}\text { DPD } \\
(\mathbf{X} 2)\end{array}$ & $\begin{array}{c}\text { INC } \\
(\mathbf{X 3})\end{array}$ & $\begin{array}{c}\text { MIL } \\
(\mathbf{X} 4)\end{array}$ \\
\hline 1 & One time & $55-60 \%$ & $>90$ days & $2-2,5$ million & $0-2 \mathrm{~km}$ \\
2 & Two times & $>60-65 \%$ & $>60-90$ days & $>2,5-3$ million & $>2-4 \mathrm{~km}$ \\
3 & Three times & $>65-70 \%$ & $>30-60$ days & $>3-3,5$ million & $>4-6 \mathrm{~km}$ \\
4 & Four times & $>70-75 \%$ & $>15-30$ days & $>3,5-4$ million & $>6-8 \mathrm{~km}$ \\
5 & $>$ Four times & $>75 \%$ & $0-15$ days & $>4$ million & $>8 \mathrm{~km}$ \\
\hline
\end{tabular}

Note: Customer Retention (RET), Mileage (MIL), Days Past Due (DPD), Loan to Value (LTV), and Monthly Income (INC)

Table 4 The Statistical Results

\begin{tabular}{lccccc}
\hline & $\begin{array}{c}\text { RET } \\
\text { (sales freq.) }\end{array}$ & $\begin{array}{c}\text { LTV } \\
(\mathbf{\%})\end{array}$ & $\begin{array}{c}\text { DPD } \\
(\text { days }\end{array}$ & $\begin{array}{c}\text { INC } \\
(\mathbf{R p})\end{array}$ & $\begin{array}{c}\text { MIL } \\
(\mathbf{k m})\end{array}$ \\
\hline Mean & 1,5 & 67,08 & 39,98 & 2.949 .458 & 5,8 \\
Median & 1 & 69 & 48 & 3.010 .000 & 6 \\
Minimum & 1 & 50 & 0 & 2.100 .000 & 2 \\
Maximum & 8 & 84 & 116 & 4.030 .000 & 24 \\
Std. Deviation & 0,8847 & 11,3313 & 22,4897 & 366.375 & 3,91 \\
\hline
\end{tabular}

Note: Customer Retention (RET), Mileage (MIL), Days Past Due (DPD),

Loan to Value (LTV), and Monthly Income (INC).

Table 5 The Results of Pearson Correlation

\begin{tabular}{lccccc}
\hline Pearson Correlation & $\begin{array}{c}\text { RET } \\
(\mathbf{Y})\end{array}$ & $\begin{array}{c}\text { LTV } \\
(\mathbf{X 1})\end{array}$ & $\begin{array}{c}\text { DPD } \\
(\mathbf{X 2})\end{array}$ & $\begin{array}{c}\text { INC } \\
(\mathbf{X 3})\end{array}$ & $\begin{array}{c}\text { MIL } \\
(\mathbf{X})\end{array}$ \\
\hline Customer Retention (Y) & 1 & & & & \\
Loan to Value (X1) & $0,147^{* *}$ & 1 & & & \\
Days Past Due (X2) & $0,114^{* *}$ & $-0,009$ & 1 & & \\
Monthly Income (X3) & $0,122^{* *}$ & $0,185^{* *}$ & $-0,015$ & 1 & \\
Mileage (X4) & $-0,329^{* *}$ & $-0,037$ & $-0,075$ & $-0,116^{* *}$ & 1 \\
\hline
\end{tabular}

**Correlation is significant at the 0,01 level (1-tailed).

Using Pearson Correlation Analysis, the hypothesis test results about the relationship between four factors with consumer retention (RET) can be known. The results are summarized in Tables 5 and 6. Based on Tables 5 and 6 , it can be seen that the amount of given disbursement to previous consumers has positive relation (Pearson correlation of 0,147 ) and significant (sig. 1-tailed is below 0,05 ) with consumer retention. The higher level of loan to value (LTV) or a large disbursement positively relates to consumer interest in returning to make purchases again. Thus, the $\mathrm{H} 1$ is accepted.

Days past due (DPD) that reflects customer credit quality also has a positive influence (Pearson correlation of 0,114 ) and significant (Sig. 1-tailed is below 0,05$)$ on the level of consumer retention. In this case, the greater number of days of arrears that a consumer has experienced will affect customer retention positively in the future. Thus, $\mathrm{H} 2$ is rejected.

Consumers' monthly income (INC) that is suspected of having a negative and significant relationship with customer retention is not accepted. In the statistical test results, it is known that the greater level of consumers' income will have a positive relation with Pearson correlation of 0,122 on the level of consumer retention. Thus, H3 is rejected.

Meanwhile, the mileage (MIL) from consumers' location to the branch offices has a negative influence (Pearson correlation of $-0,329$ ) and significant (sig. 1 -tailed is below 0,05 ) with the level of consumer 
Table 6 The Results of Sig. (1-Tailed)

\begin{tabular}{lccccc}
\hline & LTV & DPD & INC & RET & MIL \\
\hline LTV & & & & & \\
DPD & 0,311 & & & & \\
INC & 0,000 & 0,207 & & & \\
RET & 0,000 & 0,000 & 0,000 & & \\
MIL & 0,025 & 0,000 & 0,000 & 0,000 & \\
\hline
\end{tabular}

Note: Customer Retention (RET), Mileage (MIL), Days Past Due (DPD), Loan to Value (LTV), and Monthly Income (INC).

Table 7 Breakdown of Customer Retention

\begin{tabular}{|c|c|c|c|c|c|c|c|c|c|c|c|}
\hline \multirow{3}{*}{$\begin{array}{c}\text { Mileage } \\
\text { (Radius in } \\
\text { km) }\end{array}$} & \multicolumn{8}{|c|}{ Frequently of Retention } & \multirow{3}{*}{$\begin{array}{l}\text { Total Cust. } \\
\text { (a) }\end{array}$} & \multirow{2}{*}{\multicolumn{2}{|c|}{$\begin{array}{c}\text { Customer Retention } \\
\text { (1 }-7 \text { times })\end{array}$}} \\
\hline & \multicolumn{8}{|c|}{ (Customer) } & & & \\
\hline & 0* & $1 \mathbf{x}$ & $2 x$ & $3 x$ & $4 x$ & $5 x$ & $6 x$ & $7 x$ & & Count (b) & $\%(b / a)$ \\
\hline $0-2$ & 369 & 318 & 115 & 31 & 14 & 8 & 3 & 3 & 861 & 492 & $57 \%$ \\
\hline$>2-4$ & 248 & 92 & 47 & 13 & 5 & 2 & 1 & & 408 & 160 & $39 \%$ \\
\hline$>4-6$ & 553 & 118 & 37 & 9 & 1 & 1 & & & 719 & 166 & $23 \%$ \\
\hline$>6-8$ & 510 & 40 & 18 & 7 & & & & & 575 & 65 & $11 \%$ \\
\hline$>8$ & 240 & 48 & 5 & 2 & & & & & 295 & 55 & $19 \%$ \\
\hline Total & 1920 & 616 & 222 & 62 & 20 & 11 & 4 & 3 & 2858 & 938 & $33 \%$ \\
\hline
\end{tabular}

*Zero frequency of retention means numbers of the customer without repeat order.

retention. In this case, the farther consumers' location with the branch offices is, the less consumer retention will happen. Conversely, the closer the location of the consumer's domicile to the branch office is, the greater the chance that consumers will take repeat orders will be. It is inversely related to the relationship in H4. So, H4 is accepted.

The variable that has the most significant influence on consumer retention is the distance from the consumer's location to the company office. Then, further descriptive analysis will be carried out to obtain an overview of what the company must do based on the mileage approach to increase its retention level. Based on the results of data analysis using the radius (distance) approach between the location of the company office and the consumer's domicile, the breakdown of consumer behavior can be seen in Table 7.

The data in Table 7 illustrate the consumers' distribution within a certain radius from the company office. It shows that if the consumers are within a radius of $0-\mathrm{km}$ from the company office, the number of consumers will increase. However, after crossing a radius of $6 \mathrm{~km}$, the existing customer base continues to decline ( 575 consumers within a radius of $6-8 \mathrm{~km}$ and 295 consumers with a radius more than $8 \mathrm{~km}$ ). This descriptive analysis explains that the further distance from the branch office causes sales penetration to become ineffective. It leads to a decrease in the numbers of customer base.

In addition, Table 7 also illustrates the relationship between mileage and customer retention. It is reflected in how many times consumers repeat orders in the company. The customer retention column explains how many consumer compositions in a certain radius of the office location to repeat orders. In this case, it has a frequency of sales from two to eight times. Meanwhile, the total customer retention column explains how many customers have made repeat orders within a certain radius. From the data, it can also be seen that the success rate for customer retention to make repeat order also decreases along with the increase in distance from the consumers' domicile to the company office from $57 \%, 39 \%, 23 \%$, $11 \%$, and $19 \%$.

Based on data analysis, the research is in line with Kyei and Bayoh (2017). They showed a significant relationship between a product with customer retention and between service with customer retention. The product aspect in the previous research is quite identical with the loan to value. Meanwhile, service is identical with mileage, which represents easiness from customers' perspectives. The novelty of the research is from the relationship between mileage and customer retention. In the traditional and microfinancial service industry, mileage from customers' 
Table 8 Customer Analysis by Mileage and Loan to Value

\begin{tabular}{ccccccc}
\hline \multirow{2}{*}{$\begin{array}{c}\text { Mileage } \\
\text { (Radius) }\end{array}$} & \multicolumn{5}{c}{$\begin{array}{c}\text { Loan to Value } \\
\text { (percentage from collateral price) }\end{array}$} & Total \\
\cline { 2 - 6 } & $\mathbf{5 5 - 6 0}$ & $\mathbf{7 6 0 - 6 5}$ & $\mathbf{7 5 - 7 0}$ & $\mathbf{7 0 - 7 5}$ & $>\mathbf{7 5}$ & \\
\hline $0-2 \mathrm{~km}$ & 181 & 11 & 5 & 33 & 139 & 369 \\
$2-4 \mathrm{~km}$ & 116 & 5 & 6 & 51 & 70 & 248 \\
$4-6 \mathrm{~km}$ & 303 & 5 & 4 & 60 & 181 & 553 \\
$6-8 \mathrm{~km}$ & 244 & 9 & 8 & 141 & 108 & 510 \\
$>8 \mathrm{~km}$ & 128 & 6 & 1 & 40 & 65 & 240 \\
\hline Total & 972 & 36 & 24 & 325 & 563 & 1920 \\
\hline
\end{tabular}

Table 9 The Initiatives of Customer Retention

\begin{tabular}{|c|c|c|}
\hline \multirow{2}{*}{$\begin{array}{l}\text { Mileage } \\
\text { (Radius) }\end{array}$} & \multicolumn{2}{|c|}{ Loan to Value } \\
\hline & $55 \%$ to $65 \%$ & $>65 \%$ \\
\hline & $\begin{array}{c}2^{\text {nd }} \text { Priority }- \text { Cluster B } \\
\text { High Probability with Bigger Loan to Value } \\
\text { Success Rate } \mathbf{3 5 \%}\end{array}$ & $\begin{array}{l}1^{\text {st }} \text { Priority }- \text { Cluster A } \\
\text { High Probability to Retention } \\
\text { Success Rate } 46 \%\end{array}$ \\
\hline 0-6 km & $\begin{array}{l}621 \text { customers }(\mathbf{3 2 \%}) \\
\text { Near Distance, } \\
\text { Low Loan to Value }\end{array}$ & $\begin{array}{l}549 \text { customers }(\mathbf{2 9 \%}) \\
\text { Near Distance, } \\
\text { High Loan to Value }\end{array}$ \\
\hline$>6 \mathrm{~km}$ & $\begin{array}{c}4^{\text {th }} \text { Priority }- \text { Cluster D } \\
\text { Low Probability to Retention } \\
\text { (Trying with Bigger Loan to Value) } \\
\text { Success Rate } \mathbf{9 \%}\end{array}$ & $\begin{array}{c}3^{\text {rd }} \text { Priority }- \text { Cluster } \mathrm{C} \\
\text { Low Probability to Retention } \\
\text { Success Rate } \mathbf{1 8 \%}\end{array}$ \\
\hline & $\begin{array}{l}387 \text { customers }(\mathbf{2 0 \%}) \\
\text { Far Distance, } \\
\text { Low Loan to Value }\end{array}$ & $\begin{array}{l}363 \text { customers }(19 \%) \\
\text { Far Distance, } \\
\text { High Loan to Value }\end{array}$ \\
\hline
\end{tabular}

domicile to the branch office still has a significant relationship with customer retention. Even digital technology is supported.

From the results of data analysis, it is known that the most significant variable in consumer retention is the mileage from customers' domicile $(0,329)$ and loan to value $(0,149)$. Based on these two determining variables, the description of 1.920 consumers that a company has never detected can be summarized in Table 8 .

According to Table 8, it shows the distribution of consumers based on the mileage and loan to value received by the consumers when they first take the credit. The distribution of consumers is simplified into four consumer clusters. It is based on the average value of the distance of domicile and loan to value. The mean value of $5,8 \mathrm{~km}$ is rounded to $6 \mathrm{~km}$, and the value of $67,08 \%$ is grouped into $65-70 \%$ and higher. Then, the company can make several priorities and initiatives to increase consumer retention, as described in Table 9.

Based on the four clusters in Table 9, there are differences in treatment and initiatives that finance companies can carry out to increase consumer retention. The first priority is consumers who are in Cluster A. They have near mileage from their domicile to the company office and have been given high credit financing. The opportunity to retain consumers in this cluster is quite large, which is $46 \%$. There are 549 consumers ( $29 \%$ of the consumers' population) who have never been retained. Those consumers in this cluster have a relatively high opportunity to repeat orders because they have been given high credit financing on their previous orders.

The second priority is consumers who are in Cluster B. They have near distance but have never been provided with high credit financing. Opportunity for retention in this cluster is also large, with an overall success rate for consumers at $35 \%$. There are 621 consumers (32\% of the consumers' population) 
who have never been retained. Those consumers in this cluster have a relatively high opportunity to take refinancing so that the company can provide higher credit financing.

The third priority is consumers who are in Cluster C. They live in a considerable far distance from the branch office but have been given a high amount of credit. There are 363 consumers (19\% of the consumers' population) who have never been retained. However, they relatively have a relatively small level of opportunity $(18 \%)$ to take refinancing because of their relatively large distance from the branch office location. This factor arguably has the most significant influence on consumer retention in this area. Therefore, the company better prioritizes the penetration of consumers in Clusters A and B first before this cluster.

The last priority is consumers in Cluster D. They live in a considerable far distance from the branch office and have not been given a high credit facility. Extra facilities are needed to retain the consumers in this cluster. One of the ways is with more loans to value offering. However, with a considerable distance from the branch location, there is little possibility of consumer retention in this cluster. The overall success rate is only $9 \%$. Hence, the company should prioritize Cluster A first, then Clusters B and C, before penetrating consumers in Cluster D.

\section{CONCLUSIONS}

Based on the statistical results, it can be seen that the given loan to value to previous consumers has a positive and significant relation $(0,147)$ with customer retention. With this result, $\mathrm{H} 1$ is accepted. Then, the second variable, days past due from customer payment, also has a positive and significant relation $(0,114)$ with consumer retention. With this interpretation, $\mathrm{H} 2$ is rejected. Meanwhile, a customer's monthly income with a negative and significant relationship is not seen in the results of data analysis. Hence, H3 is rejected. Finally, the mileage from the customer location to the branch office is proven to have a negative and significant relation $(-0,329)$ with consumer retention. With this result, $\mathrm{H} 4$ is accepted.

The research has managerial implications for customer retention. Based on consumers' behavior and the tendency for customer retention, the following are recommendations that need to be prioritized by the company. With sensitive consumers' behavior to mileage like this, the company needs to focus on Cluster A first to increase consumer retention. In this cluster, there are $29 \%$ of consumers who have never done a repeat order. Meanwhile, other customers in this cluster have the highest retention rate $(46 \%)$. For the second priority, the company needs to prioritize $32 \%$ of the consumers in Cluster B. It is based on the general tendency that consumers in this radius have a fairly good retention rate (in the range of $35 \%$ ).

In addition to this, the research also has some limitations, so it is open for further research. For example, discriminant analysis can be done to determine what factors influence the frequency of purchase or consumer retention. Then, the grouping of consumer categories can be done based on consumers who take one-time financing, two times financing, three times financing, and so on. With discriminant analysis, it is expected to know the difference between these consumers, so the results can be used to develop appropriate marketing strategies. Further research can also be done to complete the research by distributing questionnaires from 100 customers as samples in Clusters A and B. It is to find out more specifically why consumers in these clusters have not been successfully reviewed so far. The research can be done by distributing questionnaires by sampling or conducting focus group discussions.

\section{REFERENCES}

Alfansi, L. (2016). Pemasaran jasa finansial. Jakarta: Salemba Empat.

Ascarza, E., Neslin, S. A., Netzer, O., Anderson, Z., Fader, P. S., Gupta, S., ... \& Schrift, R. (2018). In pursuit of enhanced customer retention management: Review, key issues, and future directions. Customer Needs and Solutions, 5(1), 65-81.

Almohaimmeed, B. (2019). Pillars of customer retention: An empirical study on the influence of customer satisfaction, customer loyalty, customer profitability on customer retention. Serbian Journal of Management, 14(2), 421-435.

Bahri-Ammari, N., \& Soliman, K. S. (2016). The effect of CRM implementation on pharmaceutical industry's profitability: The case of Tunisia. Management Research Review, 39(8), 854-878.

Chen, H. C., \& Green, R. D. (2011). Brand equity, marketing strategy, and consumer income: A hypermarket study. Journal of Management and Marketing Research, 8, 1-18.

Daneshfar, Z., Roshani, A., \& Sabzali, H. (2016). Evaluating customer retention and satisfaction and the reason of losing customers in the auto insurance (A case study). In Proceedings of the 2016 International Conference on Industrial Engineering and Operations Management (pp. 1-10).

Hague, P., \& Hague, N. (2016). Customer satisfaction survey: The customer experience through the customer's eyes. London: Cogent Publication.

Hanaysha, J. R. (2018). Customer retention and the mediating role of perceived value in retail industry. World Journal of Entrepreneurship, Management and Sustainable Development, 14(1), 2-24.

Haripersad, R., \& Sookdeo, B. (2018). Customer retention: Key towards sustaining competitiveness in commercial banking in South Africa. Journal of Business and Economic Policy, 5(3), 81-90.

Idrees, Z., \& Xinping, X. (2017). Impact of banking relationship characteristic on service quality dimensions and customer retention. International 
Journal of Academic Research in Economics and Management Sciences, 6(1), 2226-3624.

Kangu, M., Wanjau, K., Kosimbei, G., \& Arasa, R. (2017). Technology infrastructure: A customer relationship management dimension in maintaining customer loyalty. International Journal Economics, Commerce and Management, (5), 88-106.

Karya, S., Suhartono, J., \& Candra, S. (2017). Sales force automation dalam peningkatan pelayanan terhadap pelanggan. Ultima InfoSys: Jurnal Ilmu Sistem Informasi, 8(1), 29-34.

Kuria, J. K., \& Muturi, W. (2018). Influence of customer retention strategies on performance of commercial banks in Kenya. International Journal of Social Sciences and Information Technology, IV(X), 420433.

Kyei, D. A., \& Bayoh, A. T. M. (2017). Innovation and customer retention in the Ghanaian telecommunication industry. International Journal of Innovation, 5(2), 171-183.

Larsson, A., \& Broström, E. (2019). Ensuring customer retention: Insurers' perception of customer loyalty. Marketing Intelligence \& Planning, 38(2), 151-166.

Ling, S. S. C. (2017). The effect of supply chain management on customer retention among general practitioners in Perak: A case-study of international pharmaceutical company (Doctoral dissertation). Universiti Tunku Abdul Rahman.
Magatef, S. G., \& Tomalieh, E. F. (2015). The impact of customer loyalty programs on customer retention. International Journal of Business and Social Science, 6(8), 78-93.

Mahapatra, S. N., \& Kumar, P. (2017). Customer retention: A study on Indian banks. International Journal of Research-GRANTHAALAYAH, 5(7), 485-492.

Mendez, M., Bendixen, M., Abratt, R., Yurova, Y., \& O'Leary, B. (2015). Sales promotion and brand loyalty: Some new insights. International Journal of Education and Social Science, 2(1), 103-117.

Monferrer, D., Moliner, M. A., \& Estrada, M. (2019). Increasing customer loyalty through customer engagement in the retail banking industry. Spanish Journal of Marketing-ESIC, 23(3), 461-484.

Nguyen, H. T., Nguyen, H., Nguyen, N. D., \& Phan, A. C. (2018). Determinants of customer satisfaction and loyalty in Vietnamese life-insurance setting. Sustainability, 10(4), 1-16.

Pansari, A., \& Kumar, V. (2017). Customer engagement: The construct, antecedents, and consequences. Journal of the Academy of Marketing Science, 45(3), 294-311.

Scarff, L. J. (2017). Developing strategies for customer retention. A case study on an Irish car dealership (Doctoral dissertation). National College of Ireland 